\title{
PEMBELAJARAN DENGAN MENGGUNAKAN MULTIMEDIA DIGITAL
}

\author{
Abhanda Amra \\ Program Studi Pendidikan Agama Islam, Jurusan Tarbiyah, STAIN Batusangkar \\ Korespondensi: J1. Sudirman No. 137 Kuburajo, Lima Kaum, Batusangkar, Sumatera Barat
}

\begin{abstract}
Digitalization gives great influences on education and social lives. In education, instructional media have shifted from conventional ones to digital ones. Even, the development has greatly taken place compared to the last decades. Formerly, teachers were the only media providers and if one want to get information, they should visit information center. Nowadays, some unlimited resources are available, even in one's personal computer. In relation to using multimedia for learning must be under consideration that media is the best source of needed educational information.
\end{abstract}

Kata kunci: media, pembelajaran, multimedia, digital

\section{PENDAHULUAN}

$\mathrm{M}$ edia pembelajaran yang menggunakan bantuan komputer lebih tepat disebut dengan multimedia pembelajaran. Komputer dengan kemampuan yang demikian canggih dan hampir bisa digunakan untuk mempermudah, memperlancar, dan bahkan bisa mempercepat penyelesaian proyek-proyek besar, sudah banyak tersedia. Anak-anak SD di kota sebagian besar sudah mengenal dan bahkan bisa mengoperasikan komputer. Kemampuan komputer yang multifungsi bagi kehidupan dan kegiatan manusia, sangat diperlukan bagi dunia pendidikan khususnya untuk pelaksanaan pembelajaran dalam prakteknya, baik secara terpisah maupun dalam sistem jaringan yang luas.

Konsep pembelajaran itu sendiri asalnya dari kata Inggris, to instruct, yang dialihbahasakan menjadi pembelajaran, meskipun ia bisa memiliki beberapa makna yang lain seperti pengajaran, belajar, melatih seseorang untuk belajar, atau menyiapkan seseorang agar mau belajar (Kamus Encarta, 2009). Webster's third International Dictionary of the English Languange mencantumkan kata instructional (dari kata to instruct) dengan arti "memberikan pengetahuan atau informasi khusus dengan maksud melatih berbagai bidang khusus, memberikan keahlian atau pengetahuan dalam berbagai bidang seni atau spesialisasi tertentu". Di sini juga dicantumkan makna lain yang berkaitan dengan komando atau perintah (Yusup, 2010). Sekarang konsep pembelajaran berkembang dalam konteks yang lebih kreatif, yakni dengan adanya konsep mendapatkan nilai tambah dalam wawasan, kognisi, afeksi dan konasi. Pertanyaannya adalah siapa yang melakukan pembelajaran? Tentu jawabnya adalah manusia dengan segala aspek dan karakteristiknya, baik dalam kesendiriannya maupun dalam hubungannya dengan manusia lain secara sosial. Artinya secara personal orang belajar sepanjang hayatnya, secara sosial juga mereka belajar. 
Sekarang, bahkan organisasi pun melakukan pembelajaran guna mempertahankan kelangsungan hidupnya. Surna Tjahja Djajadiningrat, guru besar ITB dalam Orasi Ilmiah pada Sidang Terbuka ITB dalam rangka Peringatan Dies Natalis ITB ke-46, tanggal 2 Maret 2005, di Aula Barat Kampus ITB, menyatakan bahwa organisasi yang mampu berkelanjutan adalah organisasi yang mampu belajar dan kreatif, dan hal ini hanya mungkin terlaksana apabila manajemen dan pimpinan organisasi memahami adanya interaksi dan saling mempengaruhi antara jaringan formal yang memiliki rancangan dengan jaringan informal yang membentuk dirinya sendiri dalam organisasi.

Kemudian dalam sistem ekonomi klasik sistem produktivitas dihasilkan melalui proses manajemen dan teknologi dari kombinasi sumber daya alam, uang dan sumber daya manusia, sedangkan pada ekonomi baru produktivitas tumbuh dari kemampuan mendidik tenaga kerja dalam memperoleh kecakapan baru berdasarkan pengetahuan baru. Manajemen pengetahuan (knowledge management), modal intelektual (intellectual capital) dan pembelajaran organisasi (organizational learning) menjadi konsep baru yang penting dalam teori manajemen.

Pada era sekarang organisasi tidak mungkin lagi bisa bertahan hidup jika tidak pernah membelajarkan stafnya secara terprogram. Lihat saja fenomena organisasi-organisasi tradisional yang dikelola oleh perseorangan dan tidak pernah membelajarkan generasi penerusnya untuk mengembangkan organisasinya, pada generasi berikut dipastikan tidak akan bertahan. Contoh nyata yang bisa diamati dalam kehidupan sehari-hari adalah bidang-bidang usaha tradisional dengan manajemen tradisional pula, seperti pasar tradisional, warung tradisional, pedagang kaki lima yang berpola tradisional, semuanya mulai tergeser dan kalah bersaing dengan mereka yang mengembangkannya de- ngan sentuhan manajemen yang berbasis pengetahuan.

Selanjutnya belajar pada lingkup personal dan organisasi memerlukan fasilitas pembelajaran. Sumber-sumber belajar dan pembelajaran banyak sekali tersedia di sekitar kita, baik sumber belajar yang sifatnya alamiah maupun yang secara khusus dirancang untuk tujuan-tujuan belajar dan pembelajaran. Di zaman sekarang, sumber-sumber belajar dan pembelajaran yang paling dominan adalah multimedia pembelajaran. Seperti diketahui, pengertian multimedia itu sendiri cukup beragam seperti yang tercantum dalam kamus Encarta tahun 2009, sebagai berikut:

1. Film suara yang ada dalam komputer, yang meliputi program-program, software dan hardware yang bisa digunakan secara luas dalam berbagai media seperti film, video, musik, teks, grafik dan angka.

2. Penggunaan berbagai bahan dalam seni, misalnya seni lukis.

3. Penggunaan semua jenis media komunikasi, khususnya dalam marketing, seperti radio, televisi dan pers, disebut media promosi atau media marketing.

4. Penggunaan media dalam pengajaran, misalnya media film, video, gambar, lukisan dan musik, sebagai tambahan atau kelengkapan terhadap metode pengajaran dan konvensional.

Pendekatan multimedia untuk pembelajaran adalah integrasi akses terhadap informasi dalam beragam media, yakni penelusuran atau temu balik objek-objek visual dalam koleksi berbasis multimedia yang relevan untuk kepentingan belajar (Brophy, P. 2003). Dengan pola seperti ini maka masalah sinkronisasi akses atas objek dan subjek pada multimedia menjadi sangat menentukan keberhasilannya. Sinkronisasi atas objek-objek dan subjek multimedia dimaksud, haruslah bisa secara simultan dan saling berhubungan satu dengan 
yang lain, diakses oleh penyaji pada saat diperlukan. Alat-alat telusurnya juga perlu disesuaikan dengan subjek yang dirancangkannya. Misalnya, file teks, file grafik, file image, file video, file foto, dan lain-lain, itu semua harus bisa diintegrasikan dalam satu sistem akses yang menarik, yang bisa menggambarkan hal-hal sebagai berikut:

1. Sajian multimedia secara keseluruhan yang harus relevan dengan alat cariannya (navigasinya).

2. Bisa diidentifikasi secara instan, misalnya dalam waktu yang sama bisa ditayangkan beberapa file teks, grafik, dan angka, juga objek lain yang relevan.

3. Semua file dalam beragam format harus bisa dihubungkan secara sinkron.

4. Semua file gambar dalam beragam format, termasuk gambar gerak (video dan video klip) juga harus bisa ditayangkan sesuai dengan perancangnya.

Dalam perkembangan sekarang, multimedia untuk tujuan pendidikan dan pembelajaran, sudah banyak yang diintegrasikan dengan format web, tidak lagi hanya disajikan secara offline, tetapi sudah online. Format untuk multimedia integrasi yang berbasis web ini dasarnya adalah XML (eXtensible Markup Languange). Jenis multimedia ini pun bisa digunakan untuk tujuan pendidikan dan instruksional, bahkan variasinya lebih lengkap, mengingat sumber-sumber informasi visual dalam internet relatif tak terbatas, dan bentuk-bentuk sajian multimedia dimaksud pada umumnya adalah:

1. Animasi: yaitu sumber-sumber informasi visual dengan format animasi atau gerak rekaan.

2. Audio klip: yaitu sajian multimedia yang mengkhususkan diri pada objek-objek dan subjek-subjek dengan format audio. Misalnya musik, narasi, pidato, drama radio, dan sebagainya.

3. Img: yaitu sumber-sumber informasi yang berbasis image atau gambar.

4. Text: yaitu sumber-sumber multimedia yang khusus berisi file teks dan referensi relevannya.

5. Texstream: yaitu sebentuk transfer format dari teks satu ke teks lainnya atau dari grafik satu ke grafik lainnya.

6. Video: yaitu sumber-sumber informasi yang khusus mengenai video klip dengan materi khusus pendidikan dan pembelajaran.

7. Ref: yaitu media referens generik, yang bisa diangkat dari beragam konsep umum dan khusus yang dianggap menarik untuk dijadikan sumber informasi pembelajaran.

Dengan pengertian seperti itu, maka ada banyak program komputer yang bisa digunakan untuk merancang pembuatan multimedia pendidikan, termasuk di dalamnya untuk memperlancar proses pembelajaran. Dari sisi guru atau dosen, program ini bisa digunakan untuk memperjelas konsep yang abstrak menjadi tervisualisasikan.

\section{MULTIMEDIA DIGITAL}

Sekarang sudah zamannya digital, media dengan format nondigital kini sudah semakin tergeser oleh kecanggihan media digital. Lihat saja misalnya video dan audio yang berformat analog sudah sangat jarang ditemukan di pasaran. Kecuali media cetak, media jenis lain selain digital sudah sangat sulit dicari dipasaran, bahkan tampaknya media cetak pun sekarang tidak lagi menjadi primadona, atau setidaknya sudah mulai disaingi oleh kehadiran media digital, terutama dalam praktek pendidikan dan pembelajaran.

Dekade yang lalu OHP/OHT dan slide suara masih mendominasi praktek- 
praktek pembelajaran kelas, sekarang hal itu sudah mulai tergeser oleh kehadiran LCD Projector dan jenis multimedia digital lainnya yang menggunakan peralatan komputer, baik yang offline maupun yang online. Kemampuan komputer untuk kepentingan multimedia pembelajaran memang sangat mengagumkan. Dengan menggunakan satu unit komputer yang memiliki spesifikasi standar minimal pentium 3 atau 4 yang dilengkapi dengan hard disk berkapasitas minimal 40 gigabyte, banyak sekali informasi dan sumber-sumber informasi digital yang ada di alam ini yang bisa dipilih untuk dijadikan sumber-sumber belajar dengan program multimedia pembelajaran.

Kemudian pertanyaan berikutnya adalah, berapa banyak informasi yang pernah direkam orang hingga saat ini dan berapa banyak yang bisa dipilih untuk kepentingan pembelajaran dengan program multimedia? Verlyn Klinkenborg dalam sebuah tulisan di The New York Times Company dengan judul "Trying to Measure the Amount of Information That Humans Create", mengemukakan pada tahun 2002, manusia telah menyimpan sekitar lima exa exabyte informasi baru pada beragam media penyimpanan dalam bentuk paper, film, media elektronik dan optik, dan bertambah secara berlipat dalam tiga tahun terakhir. Katanya lagi, lima exabyte itu setara dengan semua kata yang pernah diucapkan manusia selama hidupnya. Sementara itu, satu exabyte itu setara dengan satu triliun gigabyte, satu gigabyte setara dengan satu juga megabyte, dan satu megabyte setara dengan 700-1000 halaman teks pada kertas ukuran A4. (Editorial Observer: Nopember 12,2003).

Kemudian sekarang pada tahun 2012 jumlah itu menjadi semakin tidak terhitung. Kita bisa membayangkan berapa banyak informasi yang sudah disimpan saat ini. Sebenarnya bukan itu tujuan tulisan ini, yang penting adalah adanya gambaran kesadaran semua orang, terutama mereka yang meminati perkembangan informasi digital, bahwa perkembangan informasi terekam sudah sedemikian pesat dan membludak sehingga semakin sulit untuk diikuti oleh siapapun, bahkan oleh mereka yang ahli di bidangnya sekalipun.

Coba direnungkan sekali lagi paragraf berikut: Berapa banyak informasi terekam yang ada di alam ini hingga saat ini? Berapa banyak informasi terekam yang terlahir pada tahun lalu di negera Indonesia? Berapa banyak informasi terekam dalam media komunikasi massa telah dilahirkan hari kemarin? Berapa banyak informasi terekam yang tercipta pada sebuah surat kabar nasional hari ini, hari esok, hari esoknya lagi dst? Pertanyaan-pertanyaan itu hanyalah untuk menunjukkan betapa informasi lahir dan terus dilahirkan setiap waktu. Ribuan bahkan jutaan jam dan menit. Tak seorang pun sanggup mengikuti seluruh perkembangan dan pertumbuhan informasi secara tuntas, bahkan seorang ahli di bidangnya sekalipun, apalagi jika informasi dimaksud tidak ada yang mengelolanya secara terinci.

Semua informasi tersebut sebagian sudah disimpan dalam memori manusia, terutama memori yang sudah dialihbentukkan ke dalam media penyimpanan yang di dunia kepustakaan dikenal dengan nama dokumen, baik dokumen analog maupun dokumen digital, yang pertama berkaitan dengan dokumendokumen konvensional, sedangkan yang digital berarti dokumen yang dihubungkan dengan teknologi informasi dan komputer. Secara umum pengelolaan informasi untuk kedua jenis dokumen tersebut, yang dari zaman ke zaman semakin berkembang dan kompleks, sekarang sudah semakin rumit seiring dengan kompleksnya jenis dan ragam dokumen yang ada. Itu semua terjadi akibat dari perkembangan pengetahuan, ilmu, teknologi, dan seni. 


\section{PEMBELAJARAN DENGAN PER- PUSTAKAAN DIGITAL}

Pada dasarnya perpustakaan digital adalah penggunaan peralatan umum untuk mengkover organisasi informasi, penggunaan teori, prinsip, dan peralatan untuk merencanakan, mengorganisasikan, assessing, dan evaluasi informasi. Selain itu prinsip lainnya adalah menekankan kepada prinsip kepentingan pengguna dalam pelaksanaan arsitektur informasi; merancang desain web interaktif, server interaktif dan penekanan pada konektifitas database serta aplikasinya pada internet. Namun dalam tulisan ini, koneksi pada internet dilepaskan dulu dengan alasan nilai fungsionalitas yang lebih diutamakan. Seperti diketahui bahwa informasi yang sudah masuk ke dalam sistem internet itu sudah bercampur dengan informasi lain yang terkadang tidak berguna sama sekali, seperti yang pernah dikemukakan oleh Herring (2001) dan Carlson (2002), yang tersedia juga di: http://chronical.com, sebagai berikut:

1. Internet banyak manfaatnya, namun bukan segalanya.

2. Di internet tidak ada katalog yang bisa digunakan untuk mencari informasi dan sumber-sumber informasi secara memuaskan.

3. Informasi yang disajikan internet, biasanya tidak ada kontrol tentang kualitas terutama informasi yang gratis-gratis.

4. Memang di internet tidak mungkin ada buku atau tulisan lengkap yang baru terbit ditampilkan secara utuh dan gratis, sebab ini menyangkut masalah hak cipta, kecuali e-book yang masih mahal harganya.

5. Meskipun sudah ada internet, sampai saat ini perguruan tinggi mana pun masih memerlukan buku sebagai koleksinya.

6. Perpustakaan maya atau dalam hal ini internet tidak akan sanggup melayani semua anggota masyarakat sewilayah jangkauan untuk komunitas tertentu.

7. Internet memang sangat banyak dan meluas, namun informasinya relatif dangkal.

8. Kalaupun ada informasi yang mendetail di internet seperti adanya $e$ book dan e-journal fulltext yang harganya mahal, sistem aksesnya juga sering bermasalah.

Sistem perpustakaan digital memang tidak sederhana seperti menggunakannya. Ia dibangun atas dasar integrasi komponen-komponen penunjangnya seperti harus memenuhi kriteria kemudahan penggunaan, tampilan yang menarik, kelengkapan fasilitas, bersifat interaktif, dan mudah disisipi entri baru di dalam sistemnya. Dalam pola cariannya, misalnya harus memenuhi syarat mudah digunakan, menggunakan bahasa yang umum dikenal oleh orang banyak, bahkan jika diperlukan sistem harus mampu mengadopsi penggunaan banyak bahasa.

Sebuah contoh sistem perpustakaan digital misalnya harus memiliki tujuan sebagai berikut:

1. Mengembangkan dan menerapkan sistem perpustakaan digital berbasis web yang diintegrasikan dengan multimedia, yang juga dilengkapi dengan pendekatan multibahasa, ini masih jarang, yang terbanyak adalah dengan Bahasa Inggris dan beberapa bahasa lainnya.

2. Mendesain dan mengembangkan sistem manajemen anotasi guna mendukung beragam aspek anotasi yang multibahasa.

3. Mendukung penyediaan pola pencarian (advanced search) dalam berbagai bahasa.

4. Mendukung tersedianya pendekatan carian yang multibahasa, juga menyediakan model teoretik pene- 
lusuran dan pencarian informasi yang multibahasa.

5. Menyediakan peralatan untuk analisis perbandingan bahasa secara menyilang.

6. Menyediakan beberapa metode display dokumentasi bahasa dalam beragam format media pada peralatan displaynya (tampilannya).

7. Bisa mendukung dan menyediakan tempat khusus bagi bahan-bahan audiovisual (Shiyong $\mathrm{Lu}$, et al. 2004).

Kita bisa lihat bahwa tampilan perpustakaan digital bisa menjelaskan apa saja yang biasa dilihat pada awal dibukanya suatu situs atau web. Ada figur perkenalan, home, identitas situs, halam kontak, halam produk, halaman layanan, halaman atau fitur kotak carian, dll. (Lihat Smith, Alastair G. 2000). Situs ini bisa offline dan online. Yang offline maksdunya adalah situs dengan alamat locallhost, tidak disambungkan dengan komputer lain baik dalam lingkungan sendiri ataupun dengan komputer lain melalui jaringan internet. Sementara itu yang online adalah situs yang secara langsung tersambung dengan sistem komputer lain dalam jarak yang dekat ataupun jauh. Tulisan ini lebih menyoroti situs yang offline untuk kepentingan pembelajaran, terutama situs yang sudah dirancang secara khusus secara offline dengan segala aspek terkaitnya yang semua informasi dan sumber-sumber informasinya sudah disiagakan dalam bentuk file-file digital.

Sebuah penelitian dalam sistem pembelajaran (Corhan 1989, dalam Curtis, Floyd, dan Winsor, 2006, penyunting Yuyun Wirasasmita) dikatakan bahwa multimedia mampu meningkatkan sampai $200 \%$ dalam pengajaran, meningkatkan daya ingat sampai 14$38 \%$ dan dapat mengurangi waktu hingga $40 \%$ untuk menjelaskan konsep tunggal dalam presentasi bisnis termasuk juga pendidikan. Di sisi lain, dengan melihat tampilan multimedia pembelajaran, penyimak, pemirsa, ataupun pihak sasaran pembelajaran, dapat menangkap data dengan sangat banyak, khususnya data kualitatif dan angka umum. Peristiwa-peristiwa menonjol dan ekstrem seperti pada peristiwa sunami Aceh dan Pangandaran, misalnya akan lebih lama dan berkesan pada pemirsanya jika ditayangkan melalui media film dibandingkan dengan jika dinarasikan secara verbal.

Pada saat sekarang salah satu alasan digunakan multimedia pembelajaran adalah untuk menarik perhatian audiens. Hal ini bisa jadi disebabkan oleh kehadiran media tersebut yang memang tergolong baru dalam dunia pembelajaran, juga karena kemampuan media tersebut yang multifungsi dan bahkan memiliki keunggulan-keunggulan tertentu dibandingkan dengan jenis media yang lain. Contoh, pergerakan darah dalam tubuh manusia bisa digambarkan secara sangat menarik dan dinamis. Juga pada proses perkembangan dan pertumbuhan setangkai bunga yang sedang mekar, multimedia sanggup menggambarkannya secara visual dengan sangat baik, misalnya dengan cara mempercepat penayangannya. Dengan gambaran seperti ini, bukan saja multimedia mampu menarik perhatian audiens, juga sekaligus mampu menggambarkan secara visual objekobjek pembelajarannya.

Pesan-pesan komunikasi pembelajaran pun menjadi sangat terbantu dengan kehadiran multimedia ini. Contoh lain, dengan pendekatan dramatis, perhatian audiens akan tetap terjaga, seperti dalam kasus banyak orang berlama-lama menonton film vedio (VCD dan DVD) yang terkadang tanpa jeda sampai tamat. Bahkan seseorang sanggup menonton film hingga semalaman tanpa istirahat. Bandingkan hal ini dengan membaca teks. Berapa lama kita sanggup membaca teks sampai jeda berikutnya. Begitulah salah satu keunggul- 
an penggunaan multimedia yang mengaplikasikan pendekatan proses dramatisasi atau yang sering dikatakan para pejabat politik sebagai "didramatisir". Metode penjelasan yang sering digunakan untuk tujuan pemaparan secara detil kasus-kasus yang secara naluriah bisa membangkitkan emosi di kalangan audiensnya. Bagaimana suatu peristiwa dijelaskan secara sangat detail terutama bagian-bagian yang bisa menimbulkan emosi audiens.

Para komunikator pendidikan seperti guru, dosen dan praktisi komunikasi lainnya di lapangan, bisa menggunakan model teori dramatisasi ini untuk tetap mempertahankan perhatian audiens. Lebih menarik lagi jika pada penjelasannya digunakan bantuan multimedia pembelajaran, sehingga pesanpesan komunikasinya lebih menarik. Selain itu, multimedia pembelajaran juga mampu menjelaskan gagasan-gagasan abstrak atau sulit secara jelas dan runtut, seperti aliran darah dan bekerjanya jantung, sistem saraf, juga cara kerja mesin. Perkembangan secara runtut waktu juga bisa dilihat secara visual, misalnya foto dan video masa kecil, masa remaja, masa dewasa, dan akhirnya masa tua bisa dilihat per-ubahanperubahannya dalam hampir semua aspek fisiknya.

Kemudian tentang contoh yang lain, yaitu peristiwa komunikasi antar subjek atau orang dalam suatu diskusi kelompok, diskusi kelas, diskusi tak berstruktur pada suatu kerumunan orang di pasar, atau di mana pun peristiwa komunikasi terjadi, bisa ditampilkan secara visual, baik dalam bentuk rekaman langsung ataupun tunda. Bentukbentuk peristiwa dan proses-prosesnya bisa diamati dan dicermati secara langsung oleh pemirsanya, oleh komunikator pembelajaran ataupun oleh sasaran didiknya. Namun demikian, multimedia pembelajaran bukanlah pengganti presentasi atau pengajaran langsung guru atau dosen, namun sebagai kelengkapan dan variasi. Bagaimanapun juga, proses komunikasi tatap muka, antar pribadi, kelompok dan komunikasi langsung lainnya, dalam kegiatan pembelajaran, sangat diperlukan. Segala "nuansa" kemanusiaan pada saat komunikasi tatap muka, akan lebih terasa. Makna gerak tubuh, roman muka, nada suara dan lainlain yang termasuk ke dalam ketegori komunikasi nonverbal, akan tampak oleh masing-masing komunikator dan akan mendapat sambutan yang seimbang dari komunikator lainnya.

\section{KLASIFIKASI MULTIMEDIA PEM- BELAJARAN}

Untuk memudahkan pengklasifikasiannya, terutama jika dilihat dari jenis informasi atau pesan-pesan yang disampaikannya, multimedia di sini dikategorikan sebagai di bawah ini dan hal ini pun bisa sekaligus dijadikan dasar untuk para praktisi komunikasi pembelajaran di lapangan dalam memilih jenis multimedia yang tepat untuk pelaksanaan pembelajarannya. Berikut adalah klasifikasi multimedia pembelajaran yang dilihat dari aspek manfaat dan pengunaannya.

1. Multimedia proses benda mati yang diam dan yang bergerak. Yang pertama maksudnya adalah benda-benda tak hidup dan tidak bergerak, baik benda yang berbentuk dua dimensi ataupun benda tiga dimensi. Yang pertama antara lain adalah gambar pada bidang datar seperti gambar, foto, lukisan, dan teks. Benda-benda seperti itu bisa diolah dengan teknik tertentu sehingga bisa menarik jika ditampilkan melalui program multimedia pembelajaran. Sementara itu yang dimaksudkan dengan multimedia benda mati bergerak adalah benda-benda yang disebutkan tadi dianimasikan atau diatur pergerakan- 
nya sehingga tampak hidup. Mesin sebenarnya termasuk ke dalam kategori ini. Proses pergerakan differensi pada gardan mobil adalah contohnya. Komputer memiliki kemampuan untuk menvisualisasikan proses mesin dimaksud.

2. Multimedia benda hidup diam dan yang bergerak. Contohnya antara lain adalah makhluk hidup bernafas yang sedang diam dan tidur. Pesan-pesan pembelajaran yang diambil dari peristiwa ini bisa beragam. Orang yang sedang tidur bisa diamati raut mukanya, apakah dalam kondisi tenang atau tidak. Sementara itu multimedia benda hidup bergerak bentuknya bisa sangat luas. Bukankah semua makhluk hidup itu bergerak ketika jaga. Bentuk-bentuk pergerakannya bisa diatur sesuai dengan prinsip-prinsip multimedia, misalnya bisa dipelankan, normal atau dipercepat, sesuai dengan keperluan.

3. Multimedia sistem alamiah. Khususnya untuk membedakan model-model multimedia jenis lainnya. Perancang multimedia ini harus mengacu kepada kepentingan ilmiah, artinya produkproduknya nanti bisa digunakan untuk kepentingan penelitian, pendidikan, dan pengembangan. Sepenggal siklus kehidupan dalam ekologi lingkungan, misalnya bisa dijadikan dasar penjelasan mengenai kearifan budaya lokal (local wisdom). Sistem urinari, sistem saraf, dan sistem peredaran darah pada manusia dan binatang, misalnya bisa divisualisasikan secara sangat menarik, dan bisa digunakan untuk membantu sistem pembelajaran.

4. Multimedia sistem sosial. Maksudnya adalah multimedia yang dirancang secara khusus untuk menyampaikan pesan-pesan pembelajaran dengan tema atau subjek sekelompok orang yang berinteraksi secara dinamis, misalnya kegiatan diskusi kelompok, seminar, lokakarya, kegiatan rapat dalam suatu organisasi dan lain-lain. Peristiwa-peristiwa sosial seperti ini bisa dijadikan bahan untuk menyampaikan pesan-pesan pembelajaran dengan pokok bahasan seperti dinamika kelompok, format diskusi kelompok, brainstorming, konwledge sharing, dan lain-lain.

5. Multimedia konsep-konsep abstrak. Ini berkaitan dengan upaya menvisualisasikan karakter, emosi, sedih, marah, senang, duka, dan sebagainya. Karakter-karakter seperti itu memang akan lebih baik jika dilihat secara langsung pada orangnya, namun tentu saja agak sulit untuk mendapatkan peristiwa seperti itu, terutama jika para tokoh dalam peran tadi tergolong orang yang sibuk, atau setidaknya tidak semua orang bisa memerankan karakter-karakter yang sesuai dengan kepentingan pembelajaran.

\section{TEKNIK PEMBUATAN PROGRAM MULTIMEDIA PEMBELAJARAN}

Ada beberapa teknik dalam membuat program multimedia, termasuk multimedia untuk tujuan-tujuan pembelajaran. Beberapa software komputer yang berbasis windows pada dasarnya bisa digunakan untuk membuat program dimaksud. Beberapa teknik pembuatan program-program multimedia pembelajaran yang menggunakan bantuan komputer berbasis windows dari microsoft, bisa dilakukan sendiri, dengan langkah-langkah yang relatif sederhana, asal saja persyaratan minimal terpenuhi yakni kemampuan dasar mengoperasikan komputer. Berikut beberapa contoh teknik pembuatan multimedia dimaksud:

1. Multimedia pembelajaran berbentuk presentasi slide. Bentuk tampilan slide pada layar komputer biasanya per lembar. Pesan-pesan pembelajarannya mirip dengan media OHP yang dibuat dalam kertas transparansi, namun di dalamnya sudah 
lebih menarik karena bisa dibuat secara dinamis. Slide pembelajaran yang dibuat dengan bantuan komputer, tidak lagi hanya menampilkan teks, grafik, atau gambar-gambar diam saja, akan tetapi bisa disertai dengan animasi tertentu secara lebih dinamis.

2. Multimedia pembelajaran berbentuk film (video) suara. Bentuknya sama dengan film-film pada VCD atau DVD yang sudah dikenal. Hanya saja pada umumnya film-film jenis ini yang beredar di pasaran adalah jenis film hiburan, bukan untuk tujuan pendidikan dan pembelajaran.

3. Multimedia pembelajaran berbentuk film animasi, yang termasuk kategori ini adalah film kartun. Film yang para pemainnya berbentuk kartun juga banyak tersedia di pasaran, khususnya untuk pengguna anak-anak, meskipun kartun untuk dewasa juga ada.

4. Teknik presentasi multimedia pembelajaran yang paling umum dilakukan dengan bantuan komputer, biasanya dengan menggunakan program Microsoft Power Point, pada paket Microsoft Office. Langkah-langkah pembuatannya pun diikuti.

\section{PERTIMBANGAN PEMILIHAN MULTIMEDIA DALAM PEMBE- LAJARAN}

1. Penggunaan multimedia pembelajaran sebaiknya atas dasar pertimbangan dan analisis bahwa media ini merupakan yang terbaik dalam menyajikan informasi pendidikan yang diinginkan. Sebab tidak ada media yang terbaik untuk semua jenis presentasi pembelajaran. Untuk menjelaskan konsep kausalitas misal- nya, maka lebih baik gunakan media lain, atau bahkan narasi verbal mungkin dianggap lebih cocok. Sementara konsep-konsep yang diangkat dari benda bergerak dan rumit, akan lebih mudah dipahami dengan menggunakan multimedia.

2. Penggunaan multimedia pembelajaran sebaiknya didasarkan analisis audiens (sasaran pendidik), misalnya disesuaikan dengan konteks, subjek, waktu dan tempat dilangsungkannya kegiatan pembelajaran. Ketika kegiatan pembelajaran dilaksanakan di lapangan, maka multimedia tidak cocok untuk digunakan.

3. Penggunaan multimedia pembelajaran sebaiknya didasarkan atas kemudahan jika digabungkan dengan media lain dalam pelaksanaan pembelajaran. Metode pembelajaran lain seperti ceramah, diskusi, tanya jawab, dan lainnya, terkadang bisa digunakan secara bergantian dalam suatu pelaksanaan pembelajaran di lapangan.

4. Penggunaan multimedia pembelajaran sebaiknya disusun dan dibuat dengan pertimbangan yang cermat, tidak asal buat, misalnya penentuan objek, setting situasi, grafik, teks, dan gambar, semuanya diatur sesuai dengan proporsinya. Faktor keindahan tampilan juga perlu dipertimbangkan dalam membuatnya, jika diperlukan bisa meminta bantuan ahlinya, seperti sutradara, ahli grafis dan pelukis.

5. Multimedia pembelajaran perlu dibuat dan disusun dengan jelas dan ringkas, namun tetap harus mengacu kepada tujuan-tujuan pembelajaran yang ditetapkan. Misalnya ketika membicarakan masalah angkah persentase dalam banyak aspek, maka susunan dalam bentuk sajian tabel atau grafik dianggap lebih cocok, dibandingkan dengan narasi verbal. 
6. Jika menggunakan layar proyektor, slide projector, atau LCD (Liquid Crystal Display) maka arahkan layarnya bisa dibaca oleh segenap audiens atau pemirsa dengan nyaman, tidak terlalu jauh atau dekat. Jika LCD dipasang di ruang kelas standar atau yang berkapasitas sekitar 30-40 kursi, maka LCD bisa dipasang di tengah depan. Yang penting usahakan semua orang yang ada di ruang tersebut bisa melihat dengan jelas.

7. Jika memungkinkan, multimedia pembelajaran tidak dihidupkan lebih awal, karena hal ini akan menjadi berkurang kesan menariknya bagi audiens atau sasaran didik.

8. Disarankan presenter pembelajaran yang menggunakan multimedia tetap berkomunikasi secara langsung dengan audiens atau sasaran didik, bukan berkomunikasi dengan multimedia itu sendiri. Perlu diingat bahwa multimedia hanyalah kelengkapan presentasi pembelajaran, bukan media yang sedang diajak berbicara.

9. Sebaiknya audiens atau sasaran didik tidak terlalu dekat dengan peralatan multimedia, sebab dikhawatirkan secara reflek audiens akan terganggu.

10. Jika diperlukan, sampaikan secara sekilas manfaat multimedia pembelajaran kepada sasaran atau audiens. Perkirakan perhatian audiens pada saat-saat tertentu ketika sedang berlangsungnya pelaksanaan pembelajaran, apakah mereka sedang memperhatikan peralatannya, para pemainnya, atau informasi yang sedang disampaikan. Pada saat itu, sebagai penyaji atau komunikator pendidikan bisa melihat garakangerakan tubuh atau mata audiens, untuk selanjutnya bisa mengalihkan perhatian mereka yang sedang tidak konsentrasi ke arah informasi pembelajaran yang sedang disampaikan.

11. Penggunaan multimedia pembelajaran hanyalah sebagai alat bantu saja, bukan sebagai pengganti pengajaran yang sesungguhnya. Proses komunikasi dialogis dan pembelajaran tetap menjadi hal yang utama dalam sistem pelaksanaan pembelajaran, sebab setiap saat audiens atau sasaran bisa bertanya dan berdiskusi secara langsung dengan instrukturnya.

12. Penggunaan multimedia pembelajaran tetap di bawah kendali dan diatur oleh instruktur atau komunikator pendidikan lainnya. Misalnya bisa menghentikan sementara sajian-sajian pada bagian tertentu yang dianggap perlu untuk tujuan penekanan pada bagian yang dianggap penting atau mengulangi sajiannya pada bagian yang penting lainnya. Pada bagian-bagian tertentu lainnya jika dianggap perlu, instruktur bisa memperlambat atau mempercepat proses objeknya melalui multimedia ini.

13. Disarankan ketika menggunakan multimedia pembelajaran, tidak monoton hanya satu jenis sajian saja, tetapi jika diperlukan kita bisa mengemukakan joke-joke tertentu guna membuat suasana menjadi segar dan hidup.

\section{PENUTUP}

Alam sudah berubah, dunia sosial dan pendidikan pun sekarang sudah berbeda jauh dengan dekade yang lalu. Kalau dulu sumber-sumber belajar itu sebagian besar dari guru yang berdiri di depan kelas, maka kini sumber-sumber belajar secara relatif tak terbatas tersedia di sekitar kita, di beragam media cetak dan digital. Kalau dulu, jika butuh informasi orang harus mendatangi pusatpusat informasi, sekarang informasilah yang dengan setia menyertai kita di manapun berada. Sekarang, sumbersumber belajar demikian mudah didapat. Kuncinya adalah gunakan beragam media pembelajaran secara lebih terprogram dan integratif. 


\section{DAFTAR RUJUKAN}

Brophy, P., 2003, "Synchronised Object Retrieval: the enhancement of information retrievel performance in multimedia environments using synchronisation protocols" Information Research, 8(4) paper 161 (Available at http://InromationR. net/ir/8-4/paper161. htm.)

Curtis, Dan B; James J. Floyd; dan Jerry L. Winsor. 2006, Komunikasi Bisnis dan Profesional. Penyunting dan kata pengantar oleh Yuyun Wirasasmita. Bandung: Remaja Rosdakarya.

Klinkenborg, Verlyn, 2003, Trying to Measure the Amount of Information That Humans Create, The New York Times Company, Editorial Observer: November 12, 2003

Knowledge Management in Asia: Experience and Lessons, 2008. Report of the APO Survey on the Status of Knowledge Management in Member Conutries (06-RP-GESUV-31-B) Published by the Asian Productivity Organization 1-2-10 Hirakawacho, Chiyoda-ku, Tokyo 102-0093, Japan.

Lukmanul Hakim, 2008, Perencanaan Pembelajaran, Wacana Prima, Bandung.

Indeks

belajar $1,62,63,64,71$

digital $1,64,65,66,71,62$

guru $62,64,67,68,71$

integratif 71

media... 1, 62, 63, 64, 65, 66, 67, 68, 69, 70,71
Pawit M. Yusup, 2010, Komunikasi Instruksional, Teori dan Praktik, Bumi Aksara, Jakarta.

Rusman, 2010, Model-model Pembelajaran Mengembangkan Profesionalisme Guru, Raja Grafindo Persada, Jakarta.

Shiyong Lu, et al. 2004 "Language engineering for the Semantic Web: a digital library for endangered languages" Information Research, 9(3) paper 176 (Available at http://InformationR.net/ir/93/paper176.html).

Smith, M.K. 2001. Kurt Lewin, available at: http/www.infed.org/thinkers/etlewin.htm.

Surna Tjahjah Djajadiningrat, 2005. Mengelola Pengetahuan dan Modal Intelektual dengan Pembelajaran Organisasi: Suatu Gagasan untuk Institut Teknologi Bandung. Orasi Ilmiah pada Sidang Terbuka ITB Peringatan Dies Natalis Institut Teknologi Bandung ke-46, tanggal 2 Maret 2005 di Aula Barat Kampus Institut Teknologi Bandung.

pembelajaran ... 1, 62, 63, 64, 66, 67, 68, $69,70,71$

pendidikan. 1, 63, 64, 66, 67, 68, 69, 70, 71

sistem ........ 1, 62, 63, 65, 66, 67, 68, 71 